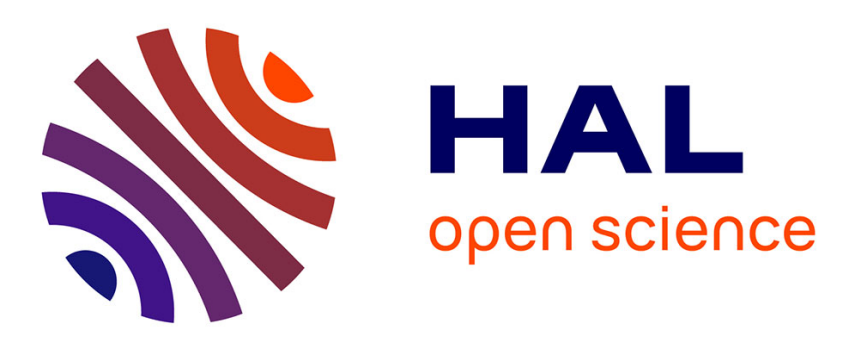

\title{
Impact of eNOS polymorphisms on red blood cell aggregation in sickle cell disease
}

Séverine Ferdinand, Philippe Connes, Laura Brudey, Kizzy-Clara Cita, Benoit

Tressières, Nathalie Lemonne, Marie-Dominique Hardy-Dessources, Yann

Lamarre, Xaxier Waltz, Maryse Etienne-Julan, et al.

\section{To cite this version:}

Séverine Ferdinand, Philippe Connes, Laura Brudey, Kizzy-Clara Cita, Benoit Tressières, et al.. Impact of eNOS polymorphisms on red blood cell aggregation in sickle cell disease. Blood Cells, Molecules and Diseases, 2015, 55 (2), pp.151-3. hal-01263890

\section{HAL Id: hal-01263890 \\ https://hal.science/hal-01263890}

Submitted on 15 Mar 2016

HAL is a multi-disciplinary open access archive for the deposit and dissemination of scientific research documents, whether they are published or not. The documents may come from teaching and research institutions in France or abroad, or from public or private research centers.
L'archive ouverte pluridisciplinaire $\mathbf{H A L}$, est destinée au dépôt et à la diffusion de documents scientifiques de niveau recherche, publiés ou non, émanant des établissements d'enseignement et de recherche français ou étrangers, des laboratoires publics ou privés. 


\section{Letter to the Editor}

\section{Impact of eNOS polymorphisms on red blood cell aggregation in sickle cell disease}

\section{To the Editor,}

Hemorheological abnormalities have been well characterized in sickle cell disease (SCD) and seem to modulate the clinical severity [1]. For instance, increased blood viscosity raises the risk for frequent vaso-occlusive crisis (VOC) and increased red blood cell (RBC) aggregates robustness (i.e., RBC disaggregation threshold) enhances the risks for acute chest syndrome (ACS) [2]. Moreover, patients with the most rigid RBCs are characterized by high hemolytic rate, which increases the risks to develop leg ulcers or glomerulopathy [3]. However, except few studies supporting an effect of $\alpha$-thalassemia and oxidative stress [1] on RBC rheological properties of SCD patients, very few experiments focused on the genetic and cellular factors modulating blood rheology in this disease.

Recently, a growing interest has been devoted to the role of nitric oxide (NO) on blood rheology in healthy individuals: NO would improve RBC deformability and decrease RBC aggregation [4]. Several variants, namely -786-TC polymorphism (rs2070744), 27 pb-VNTR repeat, 894-GT (rs1799983), have been described for the endothelial NO-synthase (eNOS) gene. These variants affect both NO production and endothelial function. One could suggest a relationship between eNOS polymorphisms, plasma NO content and hemorheological characteristics. This hypothesis is supported by the findings of Fatini et al. [5] who found an association between eNOS polymorphisms and RBC rheological properties (i.e. aggregation and deformability) in healthy individuals. However, such phenotype/genotype relationship has never been studied in SCD. The aim of the present study was to highlight eNOS polymorphisms effect on hemorheological parameters and NO levels in SCD.

SCD patients followed at the Sickle Cell Unit of Guadeloupe were included: 110 children (8-16 yrs old) and 131 adults (i.e. $\geq 18$ yrs old); 138 with homozygous SCD and 103 with sickle cell hemoglobin $\mathrm{C}$ disease. The study was approved by the Regional Ethics Committee (DIRC Sud/Ouest Bordeaux/DOM, registration number: 2009-A0021156/SAPOTILLE and 2010-A00244-35/HTA projects). All patients provided written informed consent and were at steady state (i.e. no blood transfusion or acute events in the previous three months). Hemorheological parameters were measured as previously described [2]. Plasma NO metabolites (NOx) level was measured in the pediatric cohort [6]. Genomic DNA was 
extracted from peripheral blood leukocytes and genotyped using PCR-based methods. MannWhitney/Kruskal-Wallis tests were used to compare each parameter between patients classified according to eNOS genotypes. Known parameters affecting hemorheological properties such as age, SCD genotype and hydroxycarbamide treatment were included as covariates in a linear regression model. A p $<0.05$ value was considered significant.

Baseline characteristics of sickle cell patients for clinical, biological, and hemorheological parameters are presented in Table 1. The genotypic and allelic distributions for three polymorphic variants of the eNOS gene (i.e., VNTR-27pb, 894G $>$ T and $-786 \mathrm{~T}>\mathrm{C}$ ) are also summarized. The homozygous wild types occur at higher frequency for VNTR-55, 786-TT and 894-GG polymorphisms, respectively $(43.7 \%, 69.8 \%, 84.2 \%)$. The lower frequencies were found for the homozygous mutants: $0.4 \%$ for VNTR-66, $0.4 \%$ for -786CC, and $0.9 \%$ for $894-G G$.

The RBC disaggregation threshold was significantly lower in individuals with VNTR56 or 66 genotypes compared to 55 or 45 genotypes (Table 2). Linear regression analysis revealed that VNTR polymorphisms significantly affected the RBC disaggregation threshold variability $(p=0.039)$ independently of age $(p=0.647)$ SCD genotype $(p=0.324)$ and hydroxycarbamide treatment $(p=0.249)$. No relationship was detected between eNOS polymorphisms and the other parameters. Although, the $27 \mathrm{pb}$-VNTR variant harboring 4 copies in intron 4 acts as a cis-acting regulator of eNOS expression and was previously found to be associated with a decreased eNOS expression and NO plasma level [7], this study did not detect any association between eNOS polymorphisms and NOx level in the pediatric cohort. These unexpected results need to be confirmed in larger cohorts of SCD patients but one may underline that chronic hemolysis might have affected plasma NOx level too [8].

We demonstrated for the first time an impact of eNOS $27 \mathrm{bp}$-VNTR polymorphism on the RBC disaggregation threshold variability in a large cohort of SCD patients. It is worthwhile to notice that faster RBC aggregation was previously described in subjects with the VNTR-44 or 45 genotype compared to those with the VNTR-55 genotype [9]. Altogether, these data suggest that the VNTR polymorphism modulate RBC aggregation properties. These findings may be of clinical relevance since it has been previously demonstrated that increased RBC aggregates robustness enhances the risks for acute chest syndrome (ACS) [2]. Further studies are warranted to test this hypothesis.

\section{Author contributions}


Designed the study, supervised research and wrote the manuscript: MR, PC, SF and MDHD

Performed genotyping: LB, SF and MR

Statistical analysis: SF and BT

Performed hemorheological measurements: PC, YL, XW and KCC

Recruited patients and collected clinical data: NL and MEJ

\section{Acknowledgments}

We sincerely thank the sickle cell patients who accepted to participate in the study and the medical staff of the "Unité Transversale de la Drépanocytose" at the University Hospital of Pointe-à-Pitre. This study was supported in part by the Region Guadeloupe.

\section{References}

[1] S.K. Ballas, J. Larner, E.D. Smith, S. Surrey, E. Schwartz, and E.F. Rappaport, Rheologic predictors of the severity of the painful sickle cell crisis. Blood 72 (1988) 1216-23.

[2] Y. Lamarre, M. Romana, X. Waltz, M.L. Lalanne-Mistrih, B. Tressieres, L. DivialleDoumdo, M.D. Hardy-Dessources, J. Vent-Schmidt, M. Petras, C. Broquere, F. Maillard, V. Tarer, M. Etienne-Julan, and P. Connes, Hemorheological risk factors of acute chest syndrome and painful vaso-occlusive crisis in children with sickle cell disease. Haematologica 97 (2012) 1641-7.

[3] P. Connes, Y. Lamarre, M.D. Hardy-Dessources, N. Lemonne, X. Waltz, D. Mougenel, M. Mukisi-Mukaza, M.L. Lalanne-Mistrih, V. Tarer, B. Tressieres, M. Etienne-Julan, and M. Romana, Decreased hematocrit-to-viscosity ratio and increased lactate dehydrogenase level in patients with sickle cell anemia and recurrent leg ulcers. PLoS One 8 (2013) e79680.

[4] M.J. Simmonds, J.A. Detterich, and P. Connes, Nitric oxide, vasodilation and the red blood cell. Biorheology 51 (2014) 121-34.

[5] C. Fatini, L. Mannini, E. Sticchi, E. Cecchi, A. Bruschettini, E. Leprini, P. Pagnini, G.F. Gensini, D. Prisco, and R. Abbate, eNOS gene affects red cell deformability: role of T-786C, G894T, and 4a/4b polymorphisms. Clin Appl Thromb Hemost 11 (2005) 481-8.

[6] Y. Lamarre, M.D. Hardy-Dessources, M. Romana, M.L. Lalanne-Mistrih, X. Waltz, M. Petras, L. Doumdo, A. Blanchet-Deverly, J. Martino, B. Tressieres, F. Maillard, V. Tarer, M. Etienne-Julan, and P. Connes, Relationships between systemic vascular resistance, blood rheology and nitric oxide in children with sickle cell anemia or sickle cell-hemoglobin C disease. Clin Hemorheol Microcirc 58 (2014) 307-16.

[7] T. Tsukada, K. Yokoyama, T. Arai, F. Takemoto, S. Hara, A. Yamada, Y. Kawaguchi, T. Hosoya, and J. Igari, Evidence of association of the ecNOS gene polymorphism with plasma NO metabolite levels in humans. Biochem Biophys Res Commun 245 (1998) 190-3.

[8] G.J. Kato, M.T. Gladwin, and M.H. Steinberg, Deconstructing sickle cell disease: reappraisal of the role of hemolysis in the development of clinical subphenotypes. Blood Rev 21 (2007) 37-47.

[9] M.O. Babaoglu, N. Dikmenoglu, E. Ileri-Gurel, N. Seringec, T. Zoto, U. Yasar, S.O. Kayaalp, and A. Bozkurt, Functional effects of endothelial nitric oxide synthase 
genetic polymorphisms on hemorheological parameters in healthy human individuals. Basic Clin Pharmacol Toxicol 108 (2010) 171-6.

Séverine Ferdinand ${ }^{1,2}$, Philippe Connes ${ }^{1,2,3}$, Laura Brudey ${ }^{1,2}$, Kizzy-Clara Cita ${ }^{1,2}$, Benoit Tressières ${ }^{4}$, Nathalie Lemonne ${ }^{5}$, Marie-Dominique Hardy-Dessources ${ }^{1,2}$, Yann Lamarre ${ }^{1,2}$, Xaxier Waltz ${ }^{1,2}$, Maryse Etienne-Julan ${ }^{5}$ and Marc Romana ${ }^{1,2^{*}}$

${ }^{1}$ Inserm UMR 1134, Hôpital Ricou, CHU de Pointe-à-Pitre, 97157, Pointe-à-Pitre, Guadeloupe, France

${ }^{2}$ Laboratoire d'Excellence du Globule Rouge (LABEX GR-EX), PRES Sorbonne Paris Cité, 75015, Paris, France

${ }^{3}$ Institut Universitaire de France, 75006, Paris, France

${ }^{4}$ CIC-EC 802 Inserm, CHU de Pointe-à-Pitre, Guadeloupe

${ }^{5}$ Unité Transversale de la Drépanocytose, Centre de référence maladies rares pour la drépanocytose aux Antilles-Guyane, CHU de Pointe-à-Pitre, 97157, Pointe-à-Pitre, Guadeloupe, France

*Corresponding author at: Inserm UMR_S1134, Hôpital Ricou, CHU de Pointe-à-Pitre, 97157, Pointe-à-Pitre, Guadeloupe, France. Fax: 33590590830513.

E-mail address: marc.romana@inserm.fr 
Table 1. Baseline characteristics of the studied population $(n=241)$

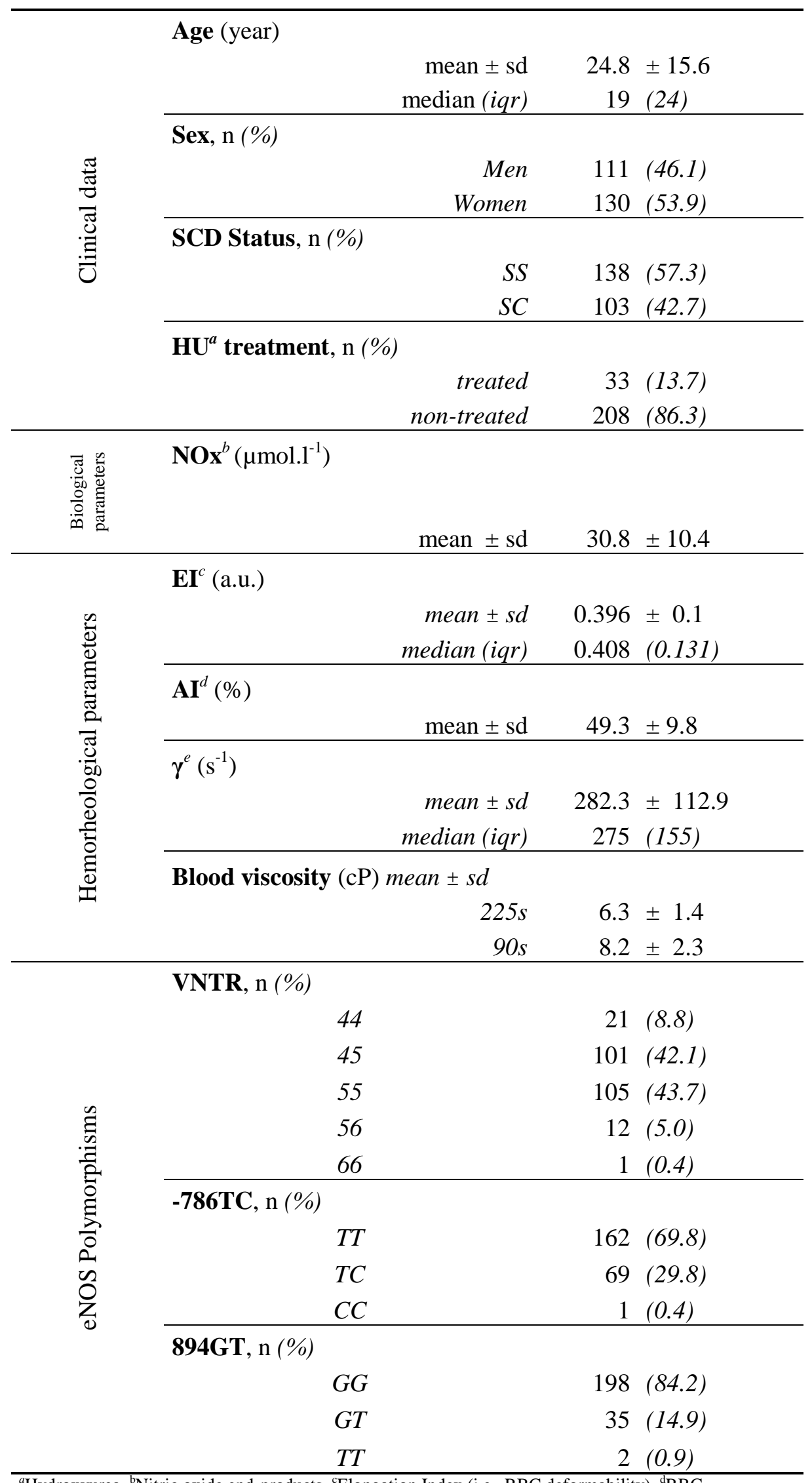

${ }^{a}$ Hydroxyurea, ${ }^{b}$ Nitric oxide end-products, ${ }^{c}$ Elongation Index (i.e., RBC deformability), ${ }^{\mathrm{d}} \mathrm{RBC}$ Aggregation Index, ${ }^{\mathrm{e}} \mathrm{RBC}$ Disaggregation threshold

SCD patients: sickle cell anemia patients (138) and sickle cell hemoglobin C patients (103);

VNTR: variable number of tandem DNA repeats

Quantitative data are expressed as mean ( \pm standard deviation/ \pm sd) or median (interquartile range/iqr)

Qualitative date are expressed as number (percentage/\%) 
Table 2. Descriptive statistics of biological and hemorheological parameters according to eNOS polymorphisms

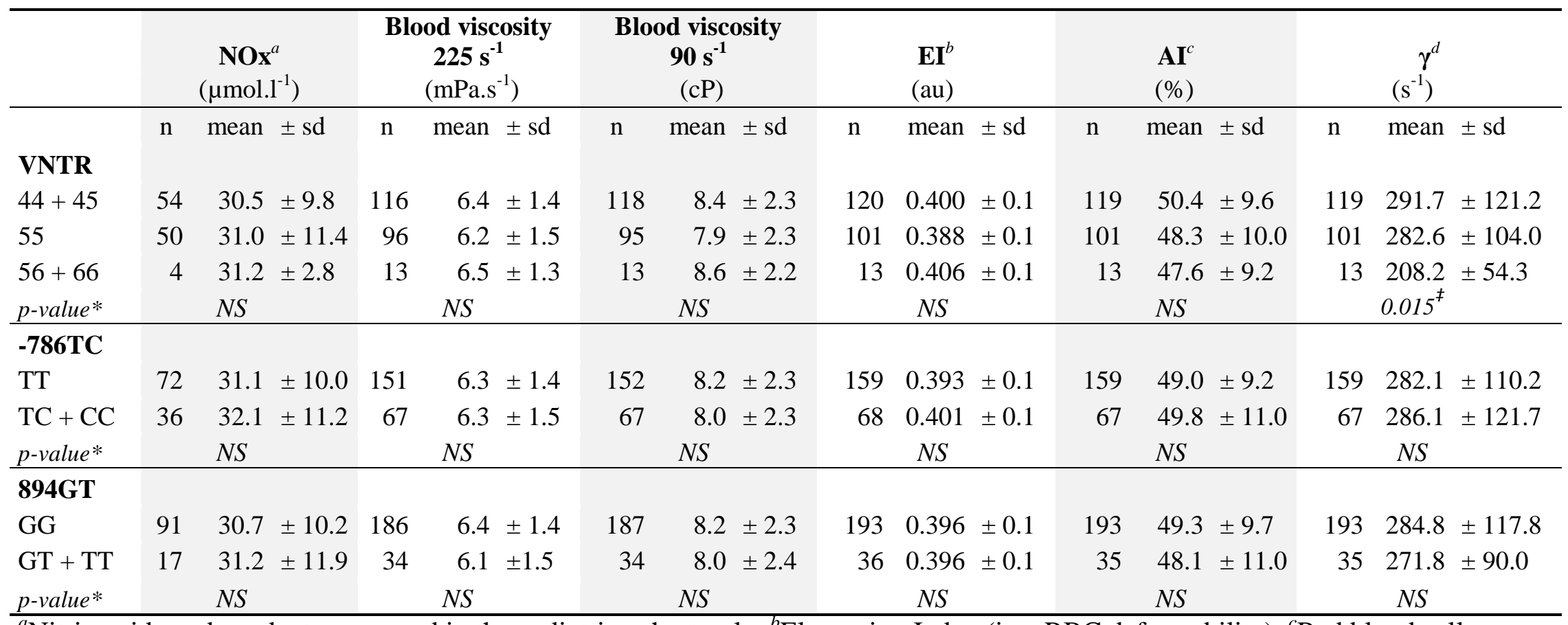

${ }^{a}$ Nitric oxide end-products measured in the pediatric cohort only, ${ }^{b}$ Elongation Index (i.e., RBC deformability), ${ }^{c}$ Red blood cell Aggregation Index, ${ }^{d}$ Red blood cell disaggregation threshold.

*by univariate analysis

${ }^{\ddagger} p$ value $=0.039$ for RBC disaggregation threshold adjusted for age, SCD status and HC treatment (multivariate analysis) 
